RADOVI

Zavoda za znanstveni rad

HAZU Varaždin

SPOMENKA VLAHOVIĆ

Zavičajni muzej Varaždinske Toplice

spomenka.vlahovic@a1net.hr
UDK 75.052:902.2(497.523Varaždinske Toplice)"652"

Prethodno priopćenje

Preliminary Communication

\title{
NEKOLIKO CRTICA O OTKRIVENIM KASNOANTIČKIM FRAGMENTIMA FRESAKA I ARHEOLOŠKIM NALAZIMA IZ ULICE BRAĆE RADIĆ U VARAŽDINSKIM TOPLICAMA
}

Primljeno: 15. 05. 2020.

Prihvaćeno: 08. 07. 2020.

DOI: 10.21857/ypn4oc1pn9 
SPOMENKA VLAHOVIĆ: Nekoliko crtica o otkrivenim kasnoantičkim fragmentima fresaka i arheološkim...

\section{ARHEOLOŠKI NADZOR I ZAŠTITNO ISKOPAVANJE U ULICI BRAĆE RADIĆ U VARAŽDINSKIM TOPLICAMA}

Arheološki nadzor i istraživanje provedeni su zbog činjenice da se navedena ulica prostire u centru grada Varaždinskih Toplica u zoni konzervatorskorestauratorske zaštite i tik uz zonu poznatog antičkog arheološkog lokaliteta Aquae lasae. ${ }^{1}$ Bogata i raznovrsna pokretna i nepokretna arheološka baština antičkog lokaliteta Aquae lasae danas nosi oznaku najviše zaštite Ministarstva kulture Republike Hrvatske, a spomenuto nalazište u Varaždinskim Toplicama svjedoči o vrlo visokom stupnju urbanizacije i ostvarenog umjetničkog stvaralaštva u ovom dijelu Rimskog Carstva i od iznimnog je značaja za nacionalnu baštinu Republike Hrvatske i teritorij Europske unije. Arheološka toplička baština danas predstavlja najbolji očuvani primjer antičke arheologije u kontinentalnom dijelu Republike Hrvatske ne samo po broju otkrivenih arheoloških nalaza već i prema visokom stupnju očuvanosti rimske arhitekture i jedinstvenog izvora termalne ljekovite vode koja se od davnina koristi na topličkom području.

Provedeni arheološki nadzor pratio je iskop bagerom i ručni iskop na navedenoj trasi jer su radovima polagane u zemlju nove plinske instalacije za srednjotlačni plinovod.

Tijekom provedenog arheološkog nadzora i istraživanja u ulici su 20. rujna 2012. otkriveni novi, dosada nepoznati dobro očuvani arhitektonski segmenti rimske građevinske strukture. ${ }^{2}$ Radnici tvrtke „Jagić d.o.o.“, koji su radili na iskopu kanala za novu plinsku instalaciju kod kućnog broja 8, zaustavljeni su u izvođenju radova zbog pronalaska više ulomaka raznih rimskih tegula i jedne manje zdjelice od keramike. Iskopani rov pružao se u smjeru istok - zapad u dužini od 15 metara. Arheološki nalazi utvrđeni su u dubini od 130 do $135 \mathrm{~cm}$. O pronalasku novog segmenta rimske arhitekture nedaleko od zone arheološkog lokaliteta Aquae lasae obaviješteno je Ministarstvo kulture i nadležni Konzervatorski odjel u Varaždinu te je, stoga, iste godine provedeno zaštitno arheološko istraživanje.

\footnotetext{
Na temelju pismenog odobrenja Ministarstva kulture Republike Hrvatske i Konzervatorskog odjela iz Varaždina u jesen 2012. godine Zavičajni muzej Varaždinske Toplice proveo je na zahtjev investitora radova firme „Termoplin d.o.o." za potrebe izvođenja radova na rekonstrukciji srednjotlačnog plinovoda u Ulici braće Radić u Varaždinskim Toplicama arheološki nadzor i zaštitno arheološko istraživanje (op.a.).

2 Novi segmenti rimske arhitekture otkriveni su ispod trase postojećeg pločnika i Ulice braće Radić, a provedeno istraživanje je potvrdilo da se protežu ispod temelja postojeće tipične topličke profane arhitekture specifične za 18. i prvu polovicu 19. stoljeća. Predstavljaju visoke prizemnice i jednokatnice čistih volumena s jednostavnim pročeljem. Objekti u prizemlju imaju konobu koja je okrenuta na uličnu zonu, a danas još uvijek imaju i očuvani svođeni prostor u prizemnom dijelu (op.a.).
} 


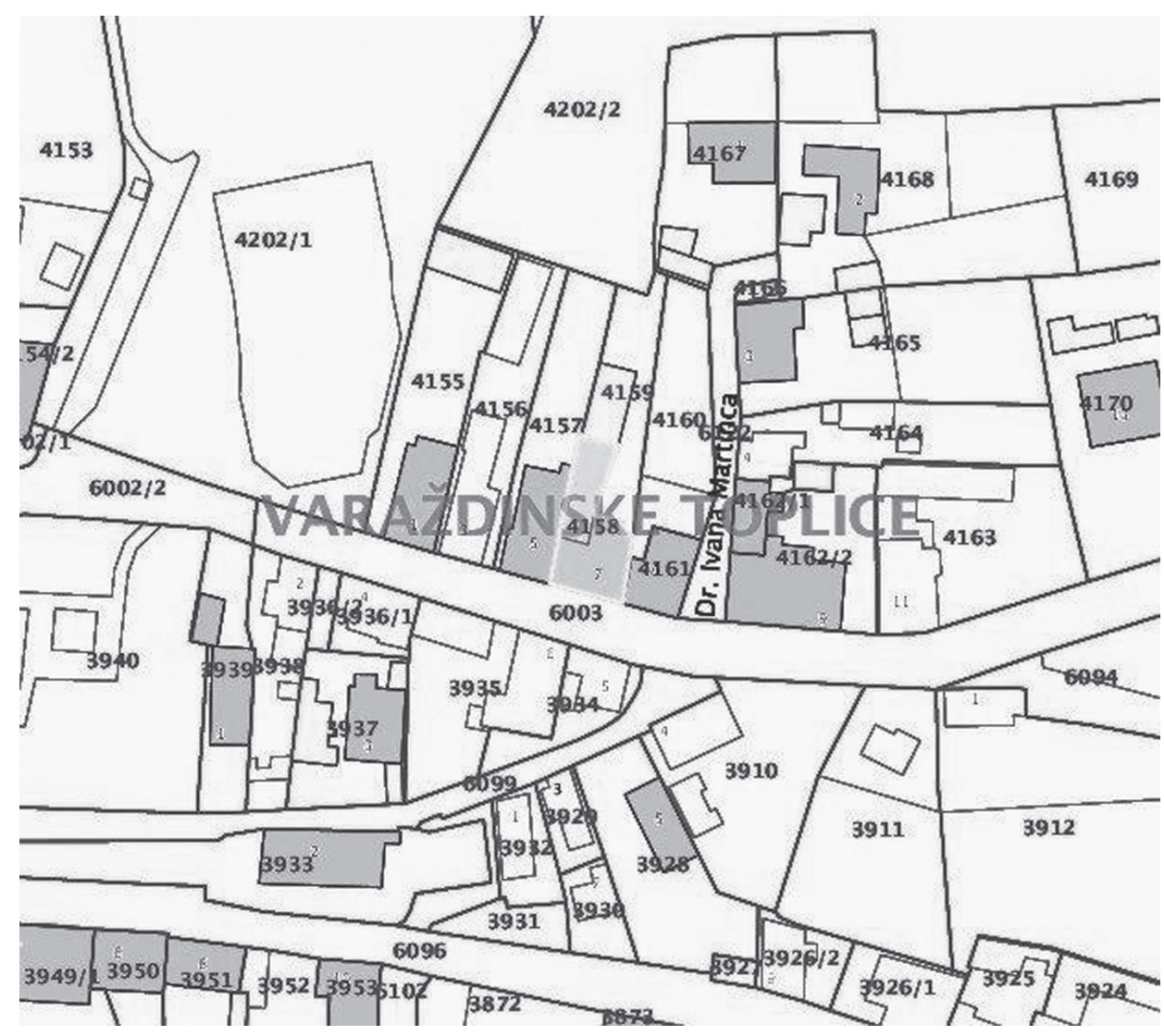

Slika 1. Detalj izvoda katastarskog plana Državne geodetske uprave za Ulicu braće Radić; arheološko istraživanje na trasi katastarskih čestica 6002/2 i6003 Katastarske općine Varaždinske Toplice, čestica s brojem 4202/1 prikazuje zonu arheološkog lokaliteta Aquae lasae 
SPOMENKA VLAHOVIĆ: Nekoliko crtica o otkrivenim kasnoantičkim fragmentima fresaka i arheološkim...

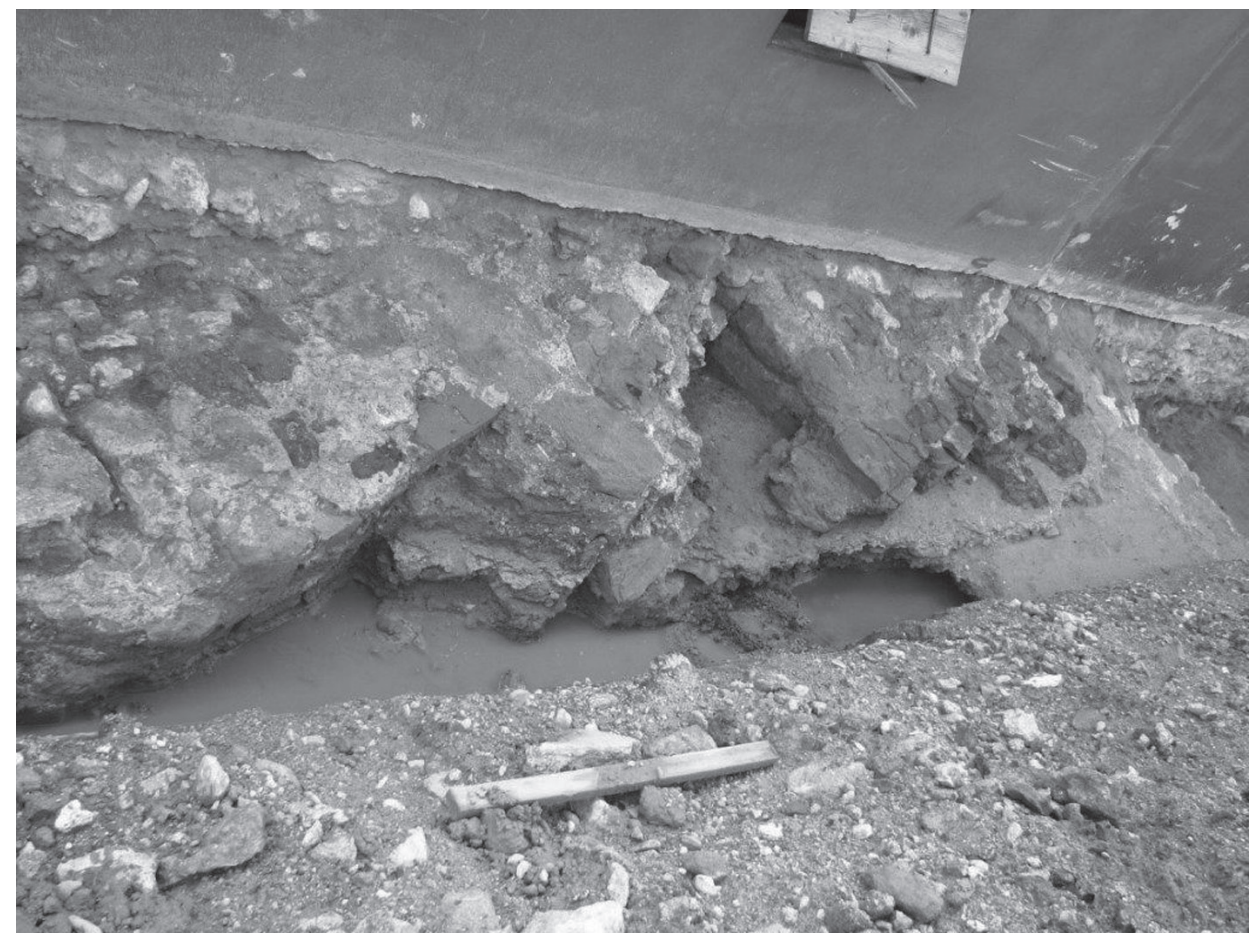

Slika 2. Pogled na otkrivenu strukturu antičkog objekta kod kućnog broja 7, Ulica braće Radić, foto: Spomenka Vlahović, 2012.

Detaljnim arheološkim pregledom i zaštitnim istraživanjima utvrđeno je da se radi o sačuvanom dijelu rimske zidne i podne strukture koja je bila izgrađena od kamena klesanca i povezana žbukom i da još uvijek na originalnim površinama ima djelomično očuvan tzv. hipokaustni sustav. Na temelju svih otkrivenih podataka potvrđeno je da se radi o važnom segmentu antičke arhitekture koji bi mogao biti dio cjeline obližnjeg urbanog tkiva arheološkog lokaliteta Aquae lasae. Lice zidne strukture otvoreno je za radove čišćenja samo s jedne strane iskopanog kanala i trase da se ne ometaju daljnji radovi na postavljanju nove plinske instalacije. Tijekom čišćenja zidova radovi su potvrdili i prisutnost tzv. rimske hidrauličke žbuke na dijelu kamenog opločenja i to na sjevernoj strani otvorenog kanala. Provedeni radovi na otkrivenoj zidnoj strukturi potvrdili su kako se na njezinoj gornjoj strani, tj. površini nalazi stara vodovodna cijev, dok se na sjevernoj strani u kanalu mogla jasno vidjeti stara plinska cijev. Na spomenutom je terenu od arheoloških nalaza pronađena veća količina rimskih tegula, ulomak keramičke 
zdjelice i dva fragmenta kamena lomljenjaka. ${ }^{3}$ Konzervatorsko-restauratorsko istraživanje tog dijela antičke arhitekture provela je iste godine za Zavičajni muzej Varaždinske Toplice diplomirana restauratorica Dagmar Dammann na zahtjev voditeljice zaštitnog istraživanja Spomenke Vlahović.

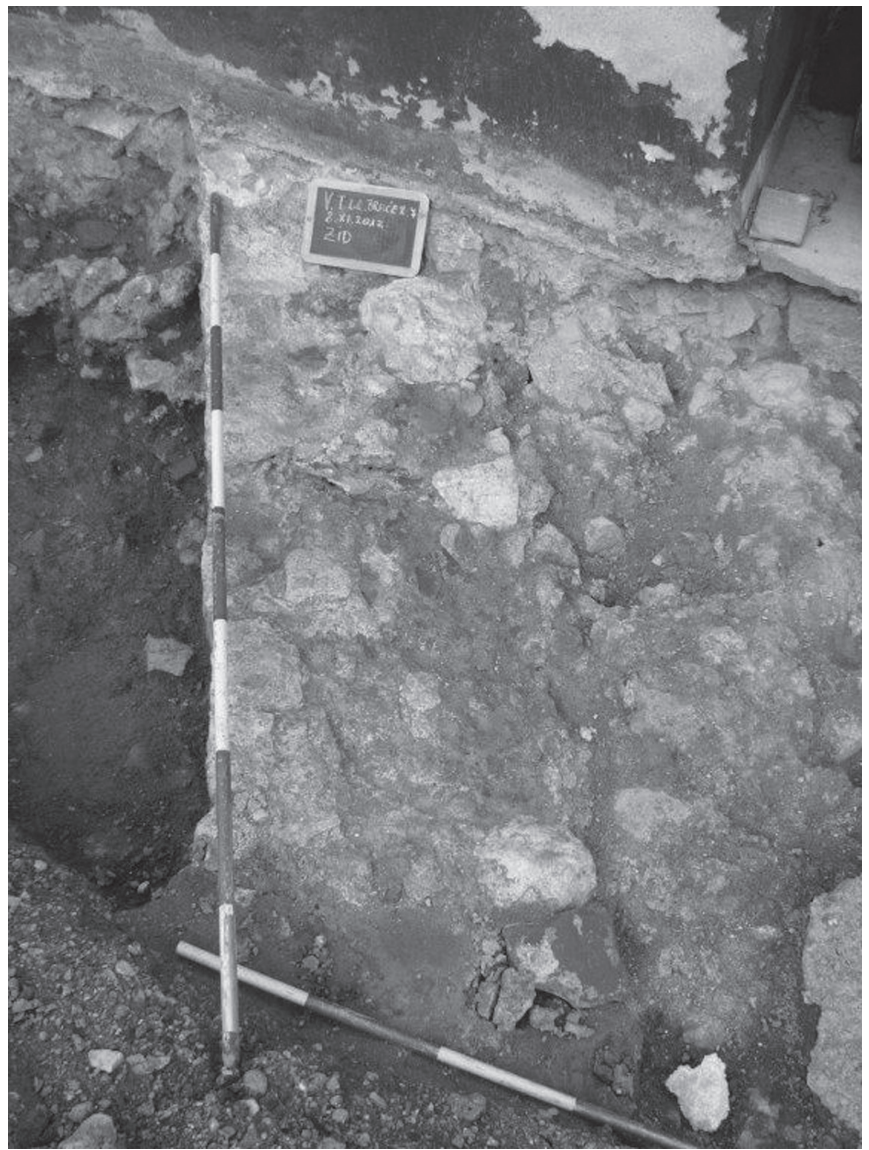

Slika 3. Pogled na dio otkrivenog zida kod kućnog broja 7, Ulica braće Radić, foto: Spomenka Vlahović, 2012.

Spomenka Vlahović, Stručno arheološko izvješće za istraživanje i nadzor u Ulici braće Radić u Varaždinskim Toplicama za potrebe rekonstrukcije srednjotlačnog plinovoda i ostalih instalacija u 2012., Zavičajni muzej Varaždinske Toplice. Uz spomenuti nalaz treba napomenuti da su prilikom provođenja drugog arheološkog nadzora iste godine za izvođača radova "Cestu d.o.o." iz Varaždina samo nekoliko metara sjevernije od prethodno opisanog segmenta, otkriveni ostaci djelomično očuvane rimske arhitekture koju su činili rimski zidovi, dijelovi arhitekture sa sustavom za zagrijavanje prostora, tzv. hipokaustom te zidne površine sa sačuvanom rimskom freskom u boji (op.a.). 
SPOMENKA VLAHOVIĆ: Nekoliko crtica o otkrivenim kasnoantičkim fragmentima fresaka i arheološkim...

\section{KONZERVATORSKO-RESTAURATORSKA ANALIZA KASNOANTIČKIH FRAGMENATA FRESAKA IZ ULICE BRAĆE RADIĆ}

Provedena konzervatorsko-restauratorska analiza u Varaždinskim Toplicama potvrdila je da se radi o rimskim zidovima koji na površinama sadrže još uvijek ostatke originalne rimske žbuke koja je služila u dekorativne svrhe i nalazila se na površinama unutrašnjih zidova rimskih prostorija. ${ }^{4}$ Ostaci hidrauličke žbuke, koja se nalazila na prikupljenim odlomljenim fragmentima, navode na zaključak da su se pojedini fragmenti ulomaka žbuke najvjerojatnije izvorno nalazili na zidovima koji su imali u svojoj zidnoj strukturi tzv. tubule kroz koje je strujao topli zrak. ${ }^{5}$ Pojedini ulomci prikupljene žbuke otkrili su na svojim površinama bojanu plohu tako da njemačka restauratorica Dagmar Dammann smatra kako postoji velika mogućnost da su bili korišteni na zidnim plohama s ciljem imitacije mramora. Jedan otkriveni očuvani ulomak žbuke na površini još uvijek sadrži vrlo dobro sačuvanu originalnu crvenu boju s ostacima tragova poteza kistom na površini. ${ }^{6}$ Konzervatorica Dammann smatra da se izvorno vjerojatno radilo o puno većoj zidnoj cjelini koja je bila obojana s nekoliko različitih boja nanijetih u slojevima.

Restauratorica Dagmar Dammann izradila je, zahvaljujući provedenom zaštitnom arheološkom nadzoru i istraživanju, vrlo detaljnu konzervatorskorestauratorsku analizu na ukupno pet prikupljenih originalnih rimskih fragmenta. U daljnjem tekstu donosimo prvi put zanimljivu konzervatorsko-restauratorsku analizu i pregled otkrivenog pokretnog arheološkog materijala. ${ }^{7}$

4 Konzervatorsko-restauratorsku analizu provela je na zahtjev Zavičajnog muzeja Varaždinske Toplice u Varaždinskim Toplicama dugogodišnja suradnica Dagmar Dammann diplomirani restaurator iz Njemačke koja radi niz godina na programu obnove rimskih fresaka i zidne antičke arhitekture na poznatom arheološkom lokalitetu Aquae lasae u Varaždinskim Toplicama (op.a. ).

5 Više podataka o tubulima i funkcioniranju hipokaustnog sistema vidi u knjizi Erika BRÖDNER „Die römischen Thermen und das antike Badewesen - Eine kulturhistorische Betrachtung" u poglavlju „Die Hypokausten“, str. 18-24, Wissenschaftliche Buchgesellschaft Darmstadt, 1983.

6 Poznato je kako su Rimljani u doba antike koristili vrlo razrađen i složen sustav paleta boja za zidnu dekoraciju kao i svijetlo-tamni kontrast, jačinu svjetlosti boja, ali i njihov točan poredak na uzorcima i teksturi kako bi na taj način likovni dojam bio na kvalitetnoj razini. Crvena boja u doba antike simbolizirala je bogatstvo i moć, a njezinim korištenjem je vlasnik objekta tako izražavao i stupanj svog bogatstva kao i određeni socijalni status u tadašnjem društvu (op.a.).

7 Dagmar DAMMANN, Untersuchung der Putzfragmente aus der Strabe Braće Radić geborgen bei Strabenbauarbeiten in Varaždinske Toplice, 7. 10. 2012, Heimatsmuseum Varaždinske Toplice, Kroatien. 
Radovi Zavoda za znanstveni rad HAZU Varaždin; br. 31, 2020, str. 9-29

Prvi analizirani fragment označen je oznakom VT BR F1. ${ }^{8}$ Radovima je potvrđeno da se cijeli fragment sastoji od tri zanimljiva konzervatorskorestauratorska sloja što se vidi na slici 5 . Prvi sloj sastoji se od hidrauličke vapnene žbuke, drugi sloj sastavljen je od grublje rimske žbuke i debljine je oko $1 \mathrm{~cm}$. U sastavu grube žbuke potvrđeno je posebno vezivno sredstvo, tj. smjesa koja se sastojala od vapna i riječnog finog pijeska veličine zrnca pijeska od 0 do $4 \mathrm{~mm}$. Vrlo zanimljivo je da je u spomenutom sloju potvrđen potpuni izostanak organskog materijala (slame ili pljeve). Treći građevinski sloj fragmenta odnosio se na finu rimsku žbuku debljine oko $1,5 \mathrm{~mm}$. Sloj je bio sastavljen od vapna, sitnih ulomaka mramora kao posebnog dodatka, dok je gornja očuvana površina nalaza bila fine obrade, tj. pokazala je jasno zaglađenu i obrađenu površinu. Fragment je od izuzetnog povijesnog i arheološkog značaja za period antike Varaždinskih Toplica jer se na njemu još uvijek nalazi očuvani rimski originalni sloj s ostacima crvene boje na površini. Na temelju dobivenih rezultata restauratorica Dagmar Dammann zaključila je kako je navedeni fragment rimske freske vrlo vjerojatno izvorno krasio neki unutarnji segment zida jer se radi o tipičnoj rimskoj žbuci koja je u periodu antike bila korištena upravo za potrebe unutarnje dekoracije prostora objekata, a sastojala se od sloja grube i fine žbuke $s$ jako zaglađenom gornjom završnom površinom. Dio otkrivenih ostataka hidrauličke žbuke na opisanom nalazu daje naslutiti kako se fragment nalazio u prostoriji koja je na zidu imala sustav tzv. tubula, tj. zidnog grijanja, i da se fragment nalazio vrlo vjerojatno upravo na strukturi takvog zida, tj. da je fragment bio dio originalne gornje završne dekoracije antičkih zidova. ${ }^{9} \mathrm{~S}$ obzirom na to da se na opisanom fragmentu kojeg prikazuje slika 4. ne nalaze tragovi oslika, može se raditi i o posebnoj imitaciji mramora ili pak o fragmentu s temom pozadinskog ukrasa freske. ${ }^{10}$

8 U tekstu se za oznaku fragmenata fresaka koriste skraćene oznake, slova VT za Varaždinske Toplice, dok se štampanim slovima BR označava lokacija Ulice braće Radić, a velikim slovom $\mathrm{F}$ označava se fragment s rednim brojem nalaza (op.a.).

9 Identična situacija s rasporedom rimskih fresaka na građevinskoj strukturi danas se može vidjeti na antičkim zidovima na obližnjem arheološkom lokalitetu Aquae lasae u gradskom parku u području rimskih terma iz 4. stoljeća u prostoriji 1 apoditerija, tzv. svlačionice na očuvanom dijelu sjeverozapadnog zida koji je spomenuta restauratorica iz Njemačke restaurirala.

10 Više o unutarnjem uređenju antičkih zidova donosi Ernst KÜNZL, „Ausstattungsluxus: Bildwerke, Brunnen, Bibliotheken“, Die Thermen der Römer, Konrad Theiss Verlag Gmbh, Stuttgart, 2013., 93. 
SPOMENKA VLAHOVIĆ: Nekoliko crtica o otkrivenim kasnoantičkim fragmentima fresaka i arheološkim...
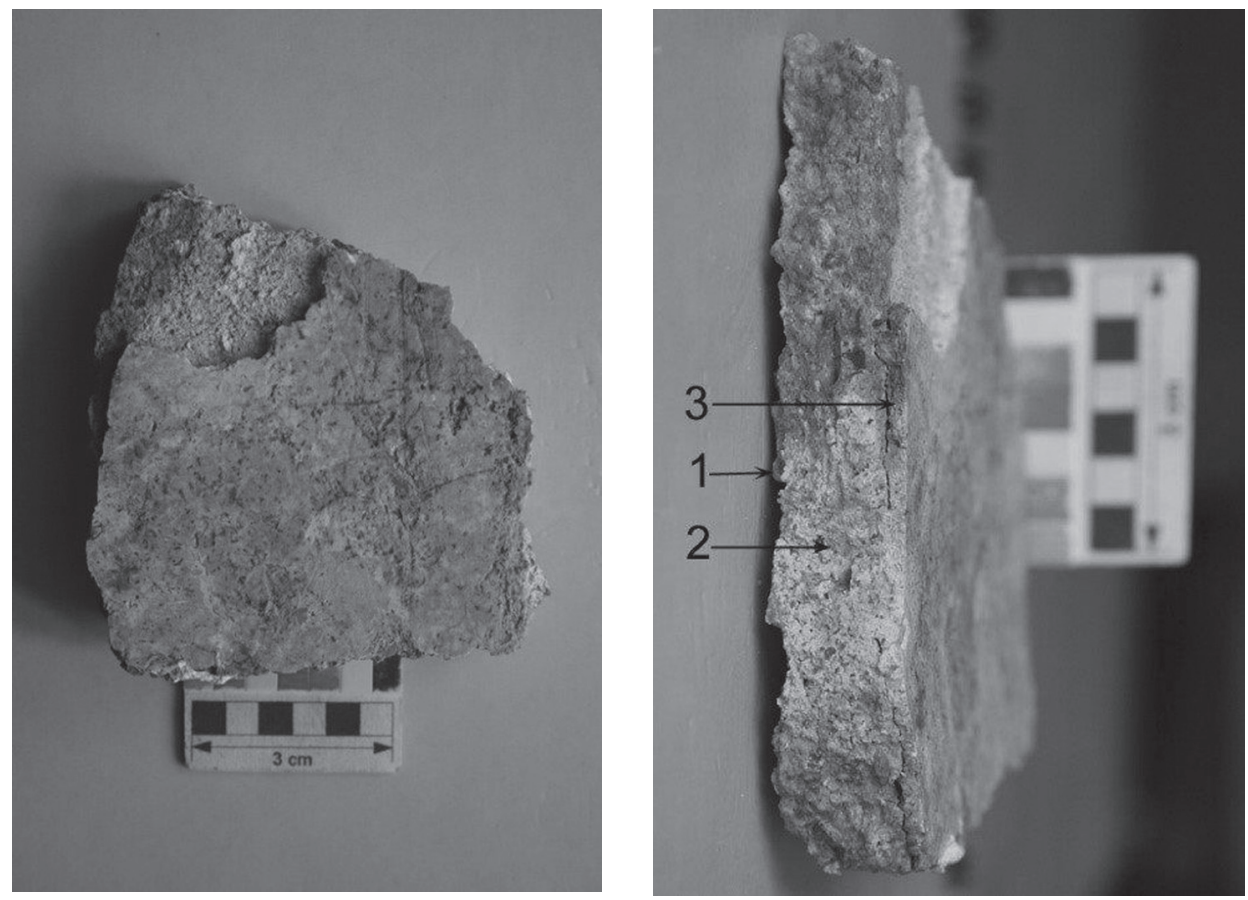

Slika 4. (L) Fragment rimske freske VT BR F1, pogled na gornju površinu, foto: Dagmar Dammann, 2012.

Slika 5. (D) Pogled na konzervatorsko-restauratorske slojeve fragmenta VT BR F1, foto: Dagmar Dammann, 2012.

Drugi fragment podvrgnut konzervatorsko-restauratorskoj analizi s oznakom VT BR F2 prikazuje očuvani rimski fragment freske unutar specifičnog topličkog većeg sedimenta geološko-arheološkog sloja, tzv. sedre. ${ }^{11} \mathrm{Na}$ ovom nalazu prikazanom na slici 6 . analiza je utvrdila da je prvi sloj neočuvan, tj. da u potpunosti nedostaje, dok se drugi sloj sastojao od grube rimske žbuke oko $1 \mathrm{~cm}$ debljine u

11 Poznato je iz raznih novijih geoloških istraživanja slojeva termalnog izvora sumporne vode na arheološkom nalazištu Aquae lasae u Varaždinskim Toplicama kako je travertin zapravo vapnenac koji nastaje u kopnenom okolišu u blizini izvora ljekovite vode. Naslage travertina su najbrže rastuće naslage kalcijevog karbonata koje nastaju direktno iz otopine. Mikroelementi koji su utvrđeni uz kalcij su najčešće natrij, magnezij, stroncij, željezo, fosfor i drugi. Znanstveno je potvrđeno da travertin Varaždinskih Toplica nastaje u vrlo aktivnom hidrotermalnom okolišu i da je za njega vrlo karakteristična pojava i prisutnost sumpora, dok lamine unutar travertinskih naslaga potvrđuju periodičke ili sezonske promjene pri taloženju. Više o provedenim analizama poznatog geološko-arheološkog sloja iz Varaždinskih Toplica vidi u: Željka ŽIGROVEČKI GOBAC, Hrvoje POSILOVIĆ i Vladimir BERMANEC, „Identification of biogenetic calcite and aragonite using Sem" Geologica Croatica 62/3. str. 201-206., Zagreb, 2009. 
nanosu. Taj sloj bio je sastavljen od vezivnog materijala vapna i riječnog pijeska kao dodatka sa zrncima pijeska od 0 do $4 \mathrm{~mm}$. Restauratorska analiza ovog nalaza, kao i prethodno opisanog, potvrdila je potpuni izostanak dodatka organskog materijala (pljeve ili slame). Treći sloj bio je sastavljen od fine rimske žbuke u debljini nanosa oko $1,5 \mathrm{~mm}$ prikazan na slici 7 . U sastavu fine rimske žbuke utvrđeno je vapno kao vezivno sredstvo te dodatak mramornog brašna i sitnih ulomaka mramora. Originalna površina rimske freske ovog nalaza pokazala je jako zaglađenu gornju površinu na kojoj se još uvijek nalaze ostaci boje. Na temelju svih analizom dobivenih podataka restauratorica Dagmar Dammann zaključila je kako je i ovaj pokretni arheološki nalaz nekada bio dio unutarnje građevinske strukture jer se radi, kao i kod prethodnog nalaza, o tipičnoj rimskoj građevinskoj strukturi. tj. žbuci tipičnoj za unutarnje uređenje zidova objekata. I kod ovog fragmenta moglo bi se, stoga, raditi o fresci s temom imitacije mramora ili pak o posebnom fragmentu s temom pozadinskog ukrasa freske..$^{12}$ Opisani pokretni nalaz iz grupe 2012. godine pronađenih fresaka pokazuje također i više različitih slojeva razne skrame kao i jasne tragove gareži, tj. utjecaja vatre i ostale tragove mehaničkih destrukcija. ${ }^{13}$
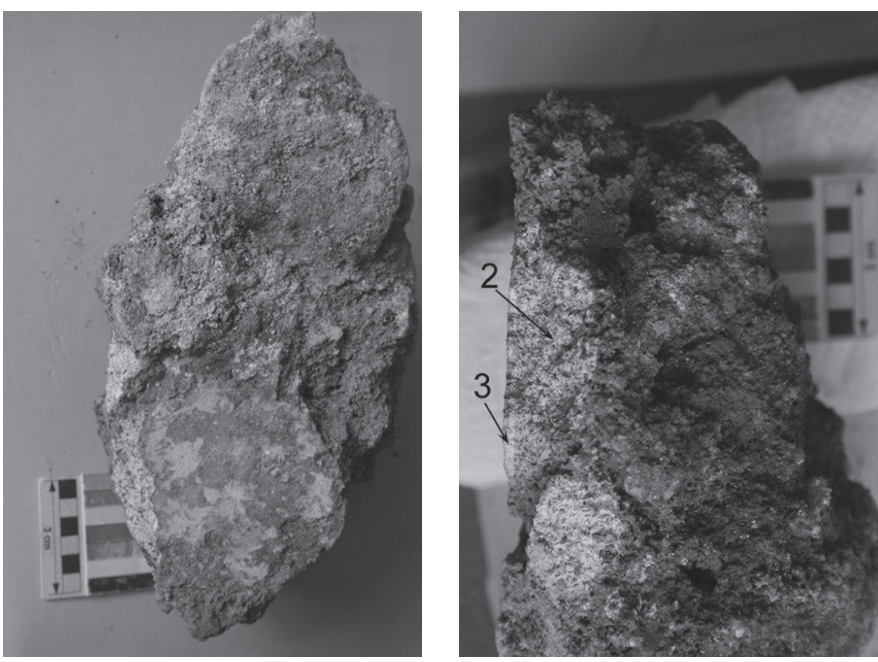

Slika 6. (L) Fragment VT BR F2, foto: Dagmar Dammann, 2012.

Slika 7. (D) Pogled na konzervatorskorestauratorske slojeve nalaza VT BR F2, foto: Dagmar Dammann, 2012.

12 Više o rimskom slikarstvu vidi u katalogu izložbe: Jasmina BAVOLJAK, Pompeji - Život u sjeni Vezuva, Galerija Klovićevi dvori, Zagreb, 2011., 192-197.

13 Arheološki sloj u ulici bio je debljine cca $110 \mathrm{~cm}$, sastojao se od raznih ulomaka sedre, gareži, ostatka raznog novijeg građevinskog materijala koji je bio izmiješan s nalazima rimske opeke, fragmentima keramike, freske i žbuke. Ostaci arhitekture nakon istraživanja su zaštićeni geotekstilom i prekriveni slojevima pijeska i sitnije batude te je iznad njih uređen novi nogostup i asfaltirana ulica, (op.a.). 
SPOMENKA VLAHOVIĆ: Nekoliko crtica o otkrivenim kasnoantičkim fragmentima fresaka i arheološkim...

Treći fragment freske s oznakom VT BR F3 prikazan na slici 8. koji je bio obuhvaćen analizom vrlo je zanimljiv konglomerat sedre u sklopu kojeg su otkriveni očuvani ostaci rimske žbuke. Analiza je potvrdila kako se radi o nalazu koji sadrži ostatke rimske freske koja pokazuje jasne tragove zaglađene i očuvane gornje površine. Na zanimljivom nalazu restauratorica je uspjela utvrditi bojane dijelove i ostatke nekadašnjeg likovnog originalnog oslika, no na temelju provedene optičke analize Dagmar Dammann nije mogla jasno potvrditi radi li se o originalnom likovno-dekorativnom sloju ili možda o slučaju kasnijeg tzv. „transfera boje“ od rimske cigle ili nekog drugog materijala na površinu nalaza. $U$ otkrivenom nalazu posebno se jasno u građevinskom kontekstu slojeva ističe originalna rimska

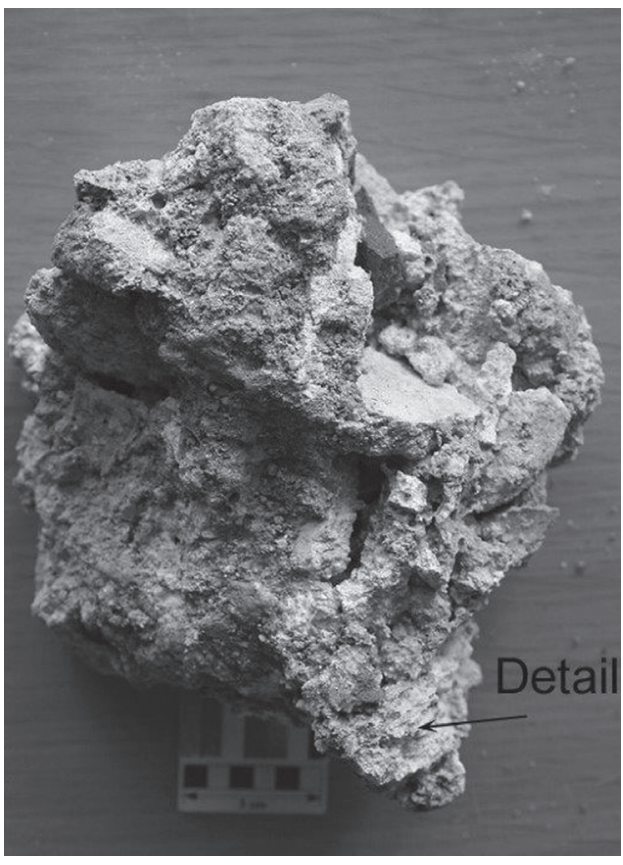
hidraulička žbuka označena na slici 9. ${ }^{14}$ Analiza je potvrdila da se sastoji od vrlo malo brašna smrvljene rimske cigle, finih sitnih ulomaka rimske cigle, komadića vapna i ostataka organskog materijala - slame. S obzirom na to kako se kod nalaza, kao što je utvrđeno, radi o fragmentu koji ne sadrži završnu gornju likovnu površinu, ne može se, nažalost, sa sigurnošću reći ništa više o njegovom izvornom točnom položaju. Vrlo vjerojatno se radi o nalazu koji je, kao i svi prethodno opisani, morao nekada stajati u unutarnjem segmentu zida neke rimske građevine. ${ }^{15}$

Slika 8. Pogled na fragment VT BR F3, konglomerat sedre $s$ fragmentima freske foto: Dagmar Dammann, 2012.

14 Rimsku hidrauličku žbuku, tzv. „opus signinum“ Rimljani su koristili pri izradi podova i onih površina koje su morale u arhitekturi biti vodootporne. Stručnjaci su u raznim istraživanjima uspjeli potvrditi da su Rimljani tu vrstu žbuke koristili u vremenskom periodu od 1. stoljeća prije Krista do 2. stoljeća nakon Krista. Danas se smatra da je navedena tehnika nastala prije 256. godine prije Krista na području sjeverne Afrike odakle se postupno proširila prema Siciliji i na talijanski poluotok. Na arheološkim lokalitetima sjeverne Afrike i u helenističkim građevinama na Siciliji postoje još danas očuvani arhitektonski kompleksi gdje je jako dobro očuvana. Više o temi vidi u digitalnoj knjižnici „Perseus Digital Library" u djelu "Naturalis Historia“ autora Plinije Starijeg na: catalog.perseus.org/catalog (op.a.).

15 O zidarskim tehnikama antike i o slikarima fresaka zanimljive podatke donose: Anita RIECHE, Hans Joachim SCHALLES, Ursula HEIMBERG, Colonia Ulpia Traiana-Arbeit-Handwerk und Berufe in der römischen Stadt, u poglavljima „Maurer“ i „Maler“, 50 -51., 52-53., Rheinland-Verlag Gmbh, Köln, 1987. 


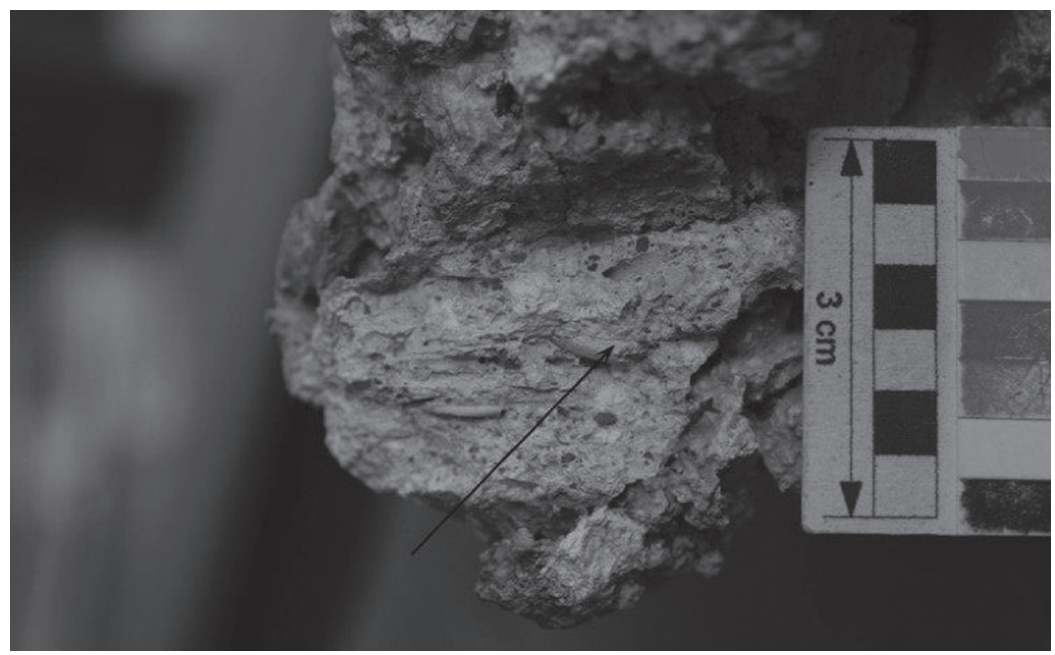

Slika 9. Pogled na sloj rimske žbuke s primjesom cigle u fragmentu VT BR F3, foto: Dagmar Dammann, 2012.

Četvrti fragment s oznakom VT BR F4 prikazan na slici 10. očuvan je fragment rimske freske s tamnocrvenim ostatkom boje na površini. Fragment se sastoji od ukupno triju očuvanih građevinskih slojeva. Prvi, donji sloj žbuke u potpunosti nedostaje, drugi sloj je izrađen u obliku grube rimske žbuke u nanosu od $1 \mathrm{~cm}$ debljine. Treći sloj fragmenta je fina rimska žbuka u nanosu od 1,5 mm debljine koja je prikazana na slici 11. Provedena analiza otkrila je da se spomenuti sloj sastoji od vapna kao glavnog vezivnog materijala, od mramornog finog brašna i sitnih ulomaka mramora. Originalna površina nalaza pokazuje jako zaglađenu gornju površinu s jasnim tragovima ostatka nekoliko poteza zaglađivanja površine. Četvrti sloj sadrži vrlo zanimljiv ostatak originalne rimske boje tamnocrvene mjestimično na površini. Restauratorska analiza Dagmar Dammann otkrila je da se ostatak boje ne nalazi na cijeloj površini fragmenta već se radi o dekorativnom ulomku na kojem se nekada vjerojatno izvorno nalazila višeslojna likovna fresko-dekoracija zida. ${ }^{16}$

16 Poznato je da su Rimljani za ukrašavanje raznih objekata koristili poznatu fresko-tehniku kao i tehniku oslikavanje vlažne žbuke na zidu, a poznato je iz raznih očuvanih antičkih lokaliteta i da su radili i likovni oslik na mokru strukturu zidova. Prilikom izrade takve tipične zidne dekoracije gornji površinski sloj žbuke morao je biti fine izrade kako bi mogao upiti sve pigmente raznih boja koje su bile korištene. Određene boje za likovnu dekoraciju zidova izrađivali su usitnjavanjem raznih minerala poput olova, željeznog oksida, cinobera ili okera, a dio su boja dobivali iz biljnih materijala. Prilikom izvođenja radova koristili su razne vrste kistova, gladilice i sl. (op. a.). Više o zidnim slikama vidi u djelu Marka Vitruvija Polliona Deset knjiga o arhitekturi, VII. knjiga, poglavlje V.: „O zidnim slikama“, str. 148-149., prijevod s latinskog dr. Matija Lopac, izdanje Svjetlost. 
SPOMENKA VLAHOVIĆ: Nekoliko crtica o otkrivenim kasnoantičkim fragmentima fresaka i arheološkim...
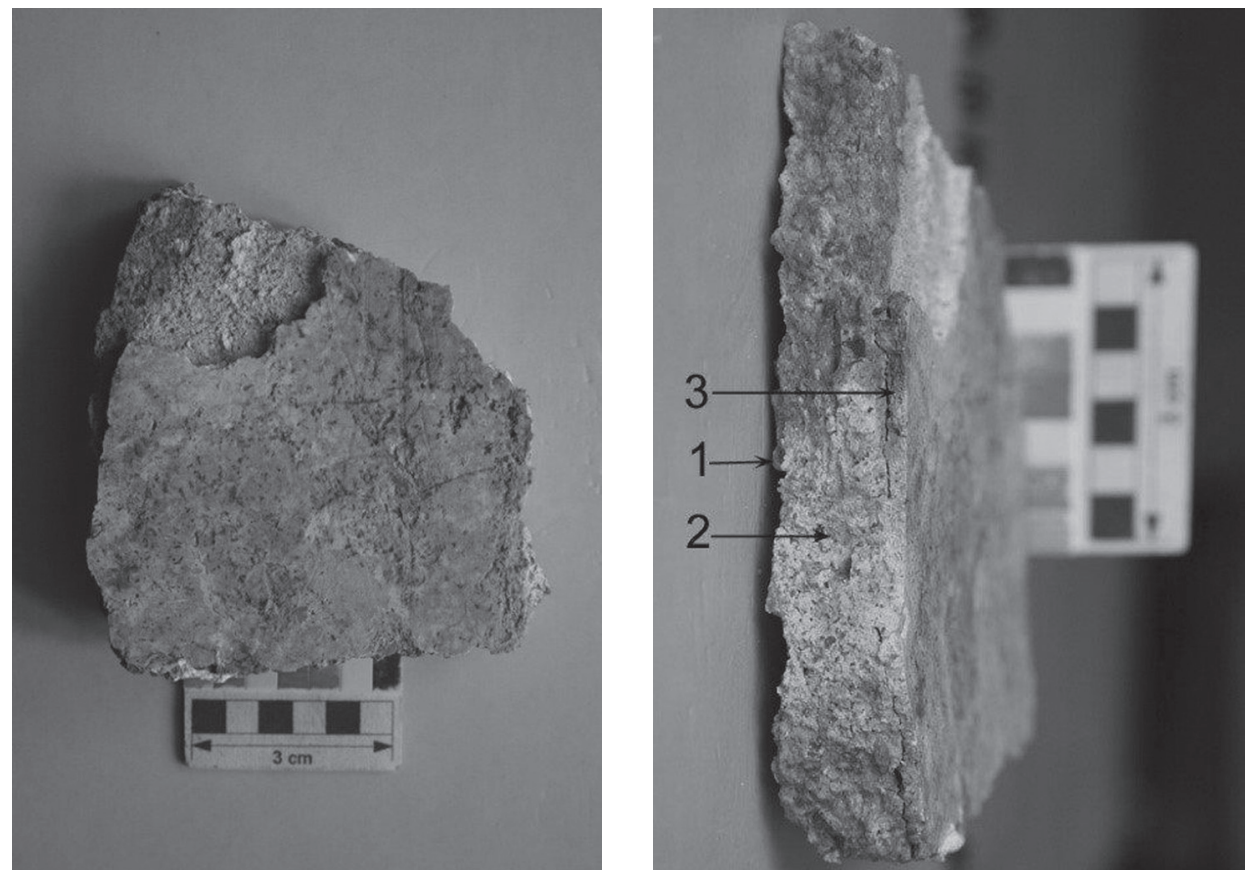

Slika 10. (L) Pogled na originalnu površinu fresko-fragmenta VT BR F4 s ostacima crvene boje, foto: Dagmar Dammann, 2012.

Slika 11. (D) Pogled na konzervatorsko-restauratorske slojeve fragmenta VT BR F4, foto: Dagmar Dammann, 2012.

Posljednji fragment s oznakom VT BR F5 prikazan na slici 12. odnosi se na neobičan fragment rimske hidrauličke žbuke. Tijekom analize utvrđeno je kako se radi o jednom ulomku sloja rimske žbuke, te se zbog toga, nažalost, ne može više mnogo reći o njegovoj građevinskoj strukturi jer nedostaju u potpunosti ostali slojevi strukture. Hidraulički fragment rimske žbuke sastoji se od finog sitnog brašna usitnjene rimske cigle, vrlo sitnih ulomaka rimske cigle, ali i sitnih komadića vapna. Provedenom analizom potvrđeno je, da je fragment vrlo vjerojatno izvorno bio dio veće građevinske unutarnje strukture nekog rimskog objekta. Svi dodaci rimskoj žbuci, poput sitnih ulomaka rimske cigle, finog brašna od cigle i sitnih ulomaka vapna, ukazuju na identifikaciju nalaza u vidu završnog gornjeg sloja žbuke koja se u doba antike koristila u gradnji zidnih površina ili u unutarnjem uređenju kupališnih bazena. ${ }^{17}$

17 Više o antičkim majstorima slikarima zidnih dekoracija donosi: Andrea GIARDINA, Der Mensch der 


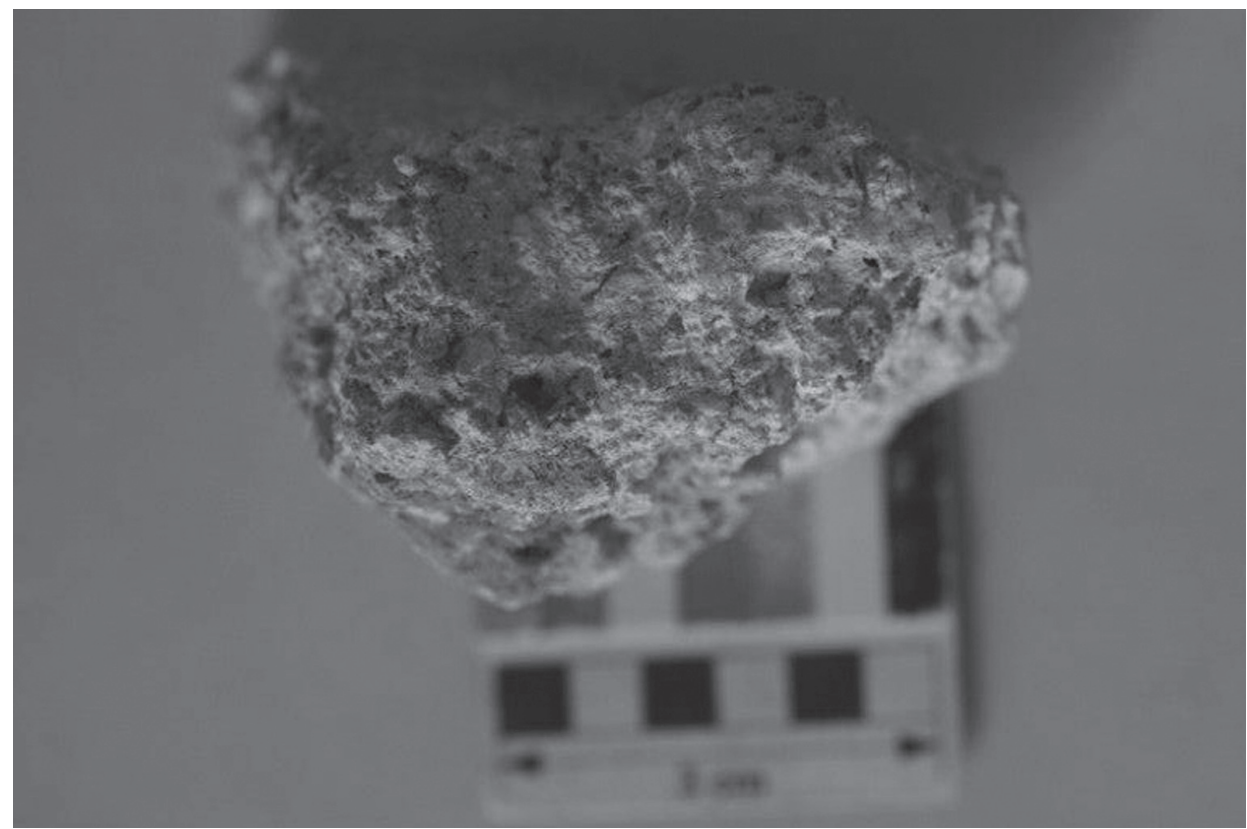

Slika 12. Nalaz hidrauličkog fragmenta VT BR F5, foto: Dagmar Dammann, 2012.

\section{OSTALI POKRETNI ARHEOLOŠKI NALAZI S LOKACIJE ULICE BRAĆE RADIĆ U VARAŽDINSKIM TOPLICAMA}

Svi otkriveni fragmenti razne uporabne keramike mogu se datirati u rimski period. Na temelju provedene arheološke analize i obrađenog pokretnog arheološkog materijala fragmenti keramike mogu se podijeliti u nekoliko vrsta s obzirom na kvalitetu materijala i obradu, tehniku izrade, boju i ostale keramičke karakteristike i oblike nalaza. ${ }^{18}$ Grupu tzv. narančaste keramike čine nalazi od kojih se većina odnosi na ulomke manjih niskih zdjelica i plitkih tanjura. Većina fragmenata je od fino pročišćene gline. U ovoj skupini nalaza izdvaja se po likovnom ukrasu fragment pod br. 33. koji pripada maloj zdjelici koja sa vanjske strane sadrži ukras u obliku dviju horizontalnih traka. Prema strukturi izrade pripada grupi keramike

römischen Antike u poglavlju autora Jean-Paul Morela „Der Handwerker“, Magnus Verlag Gmbh, Essen, 2004., 243-276.

18 Stručnu arheološku analizu prikupljenog pokretnog materijala s lokacije Ulice braće Radić u Varaždinskim Toplicama izradila je Spomenka Vlahović, diplomirana arheologinja, u Zavičajnom muzeju Varaždinske Toplice u periodu 2012. - 2013. godine. 
tzv. debljih stijenki. Druga zdjelica u ovoj grupi sadrži na površini crveni premaz i uvrštena je u grupu keramike tankih stijenki. Većina nalaza iz ove grupe keramike može se svrstati u grupu keramike tankih stijenki. Druga grupa keramike utvrđena u arheološkoj analizi je keramika sivocrne boje. Većina nalaza odnosi se na razne dijelove zdjelica, plitke tanjure i zdjelice s ravnim dnom. Dio spašenih nalaza fine je obrade i tankih stijenki, dok je drugi dio nalaza grube obrade i debljih stijenki. U ovoj grupi nalaza posebno se po ukrasu izdvaja nalaz pod brojem 39 fragment zdjelice tamnosive boje, a izdvaja se zbog očuvanog ukrasa s vanjske strane u obliku zareza izvedenih kratkom tankom linijom. Nalaz je izrađen od fino pročišćene gline i spada u grupu keramike tankih stijenki. $U$ ovoj grupi nalaza ističe se nalaz pod rednim brojem 40 koji se odnosi na dio male zdjelice sivocrne boje s ukrasom izvedenim tehnikom otiskivanja-utiskivanja u obliku sitnog četverokuta u horizontalnom smjeru po cijeloj površini. Fragment je izrađen od nepročišćene gline i uvršten je u grupu keramike debljih stijenki. Dio nalaza iz ove grupe većinom je izrađen od nepročišćene gline, debljih je stijenki i sivocrne boje, što je glavna karakteristika rimske svakodnevne uporabne keramike tzv. provincijskog tipa. Otkriveno je ukupno 10 fragmenata keramike sivocrne boje koje se odnose na dijelove zdjelica i plitke tanjure. Otkriveni nalazi podudaraju se u oblikovanju i stilu sa arheološkim nalazima istraživanja antičkog lokaliteta Aquae lasae od 1953.- 1955. koje su vodili Branka Vikić Belančić i Marcel Gorenc iz Arheološkog muzeja u Zagrebu. ${ }^{19}$

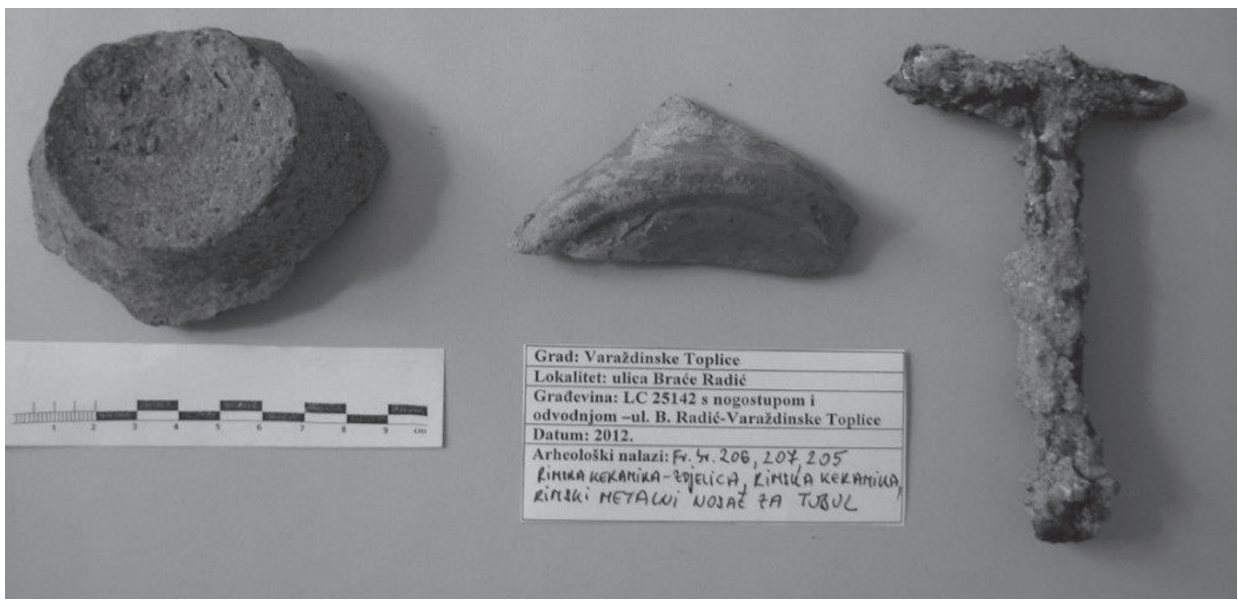

Slika 13. Fragmenti rimske keramike i metalni nosač za tubul sa lokacije Ulice braće Radić, foto: Spomenka Vlahović, 2012.

19 Branka VIKIĆ-BELANČIĆ, Marcel GORENC, „Arheološka istraživanja antiknog kupališta u Varaždinskim Toplicama od 1953.-1955., Vjesnik Arheološkog muzeja u Zagrebu, Zagreb, 1958. 
Radovi Zavoda za znanstveni rad HAZU Varaždin; br. 31, 2020, str. 9-29

Tijekom arheoloških radova na spomenutoj lokaciji prikupljena je i veća količina fragmenata ljudskih kostiju. Dio nalaza odnosi se na fragmente ljudskih zubiju, vilica "mandibule“ kao i razne fragmente ljudskih lubanja, kralježaka, kostiju podlaktica i rebara. Većina nalaza u vrlo je lošem stanju očuvanosti, neki sadrže na površini jasne tragove gareži i sitne rupice s naznakom raznih bolesti i tragove trauma.

Posebna skupina nalaza su fragmenti obrađenog kamena. U ovoj skupini izdvaja se nalaz pod brojem 141 koji sadrži još uvijek ostatke originalne obrađene površine u obliku istaknutog rebra i spiralnog ukrasa. Mislimo da bi nalaz mogao biti dio kapitela. ${ }^{20}$ I za ostala dva nalaza iz ove skupine držimo da bi također mogli biti elementi arhitekture stupova.

Grupu pokretnih nalaza predstavljaju i originalni ostaci posebnog geološkog topličkog sloja tzv. sedre koji svjedoče o taloženju veće količine termalne vode na navedenom području u određenom periodu.

Nakon provedene analize ukupnog materijala izdvojena je i grupa metalnih nalaza. Radi se o nalazima korodiranih čavli i jedan poseban nalaz koji prikazuje originalni rimski metalni nosač u obliku slova T za montažu tzv. tubula na zidnu konstrukciju. ${ }^{21}$ Ta vrsta elementa bila je korištena u rimskoj građevinskoj tehnici u prostorijama koje su bile opremljene posebnim sustavom grijanja poznatim pod terminom „hipokaustni sustav“.22

Posebnu grupu nalaza arheološkog materijala čine brojni fragmenti rimskih opeka. Većina nalaza izrađena je od fino pročišćene gline, na površinama su jasno vidljivi tragovi obrade u vidu linija, a neki sadrže i tipične polukružne liniježlijebove u kojima se još uvijek može vidjeti očuvana kvalitetna rimska žbuka, zatim slojevi sedre i ostala skrama. Jedan fragment u skupini se posebno izdvaja jer prikazuje zanimljiv otisak pasje šape na površini.

\footnotetext{
20 Nalaz bi mogao biti dio srednjovjekovnog kapitela (op.a.).

21 Više o tubulima i metalnim nosačima T oblika vidi u članku: Spomenka VLAHOVIĆ „Prikaz konzervacije tubula u prostoriji 1 u području terma antičkog kompleksa Aquae lasae u Varaždinskim Toplicama“, Historia Varasdiensis: časopis za varaždinsku povjesnicu, Vol.1. No. 1, Varaždin, 2011., str. 43-53.

22 Ista vrsta nalaza originalnih metalnih nosača za tubule danas se još uvijek može vidjeti na zidovima rimskih terma antičkog lokaliteta Aquae lasae u prostorijama apoditerija (op.a.).
} 
SPOMENKA VLAHOVIĆ: Nekoliko crtica o otkrivenim kasnoantičkim fragmentima fresaka i arheološkim...

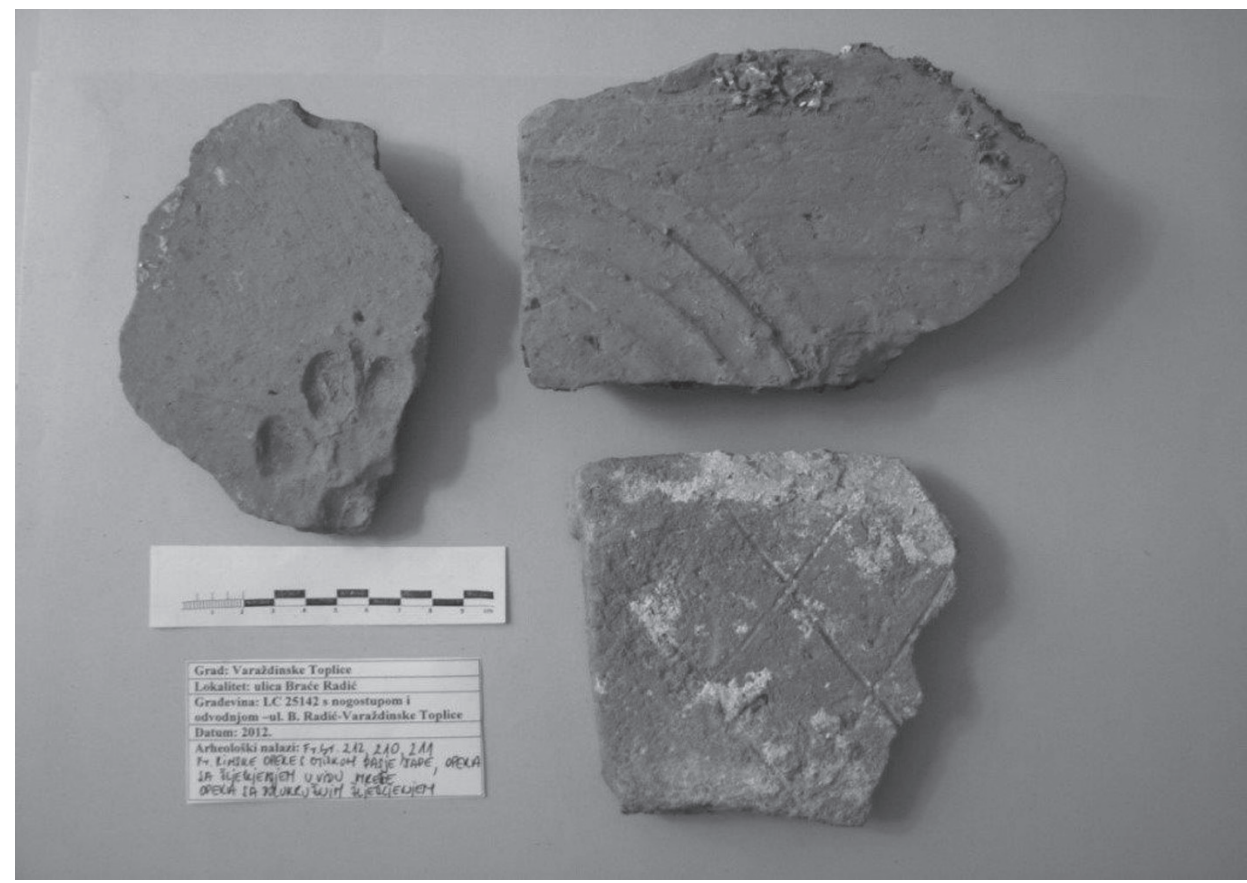

Slika 14. Fragmenti rimskih opeka s tragovima otiska pasje šape, žlijebljenja i rombova, foto: Spomenka Vlahović, 2012.

Drugu grupu rimskih građevinskih nalaza predstavljaju fragmenti rimske podne opeke. Iz bogate rimske građevinske povijesti poznato je kako su Rimljani ovu vrstu opeke koristili za popločavanje podova raznih objekata. Rimski pod u presjeku se sastojao većinom od gline u donjem segmentu na koju bi stavili i nabili lomljeni kamen i na njega zatim u drugom sloju još nanijeli rimsku žbuku i zatim na kraju, na tako pripremljenu podlogu, polagali bi opeke. ${ }^{23}$ Otkrivene podne opeke karakteriziraju jasni ostaci rimske žbuke na površinama. Većina nalaza u građevinskoj strukturi pokazuje kako je glini ilovači pridodan agregat u obliku sitno izmrvljenih zrnaca cigle, većina nalaza je narančaste boje pečenja, a samo manji dio nalaza je izrazito tamnocrven. U ovoj skupini nalaza zanimljiv je nalaz pod rednim brojem 179 koji pokazuje još uvijek očuvane tragove-ostatke poteza prstima po glinenoj površini.

23 Više o tehnici polaganja podova vidi u knjizi Marcusa Vitruviusa Pollia „Deset knjiga o arhitekturi“ u poglavlju VII „O polaganju podova“, str. 142-144. 


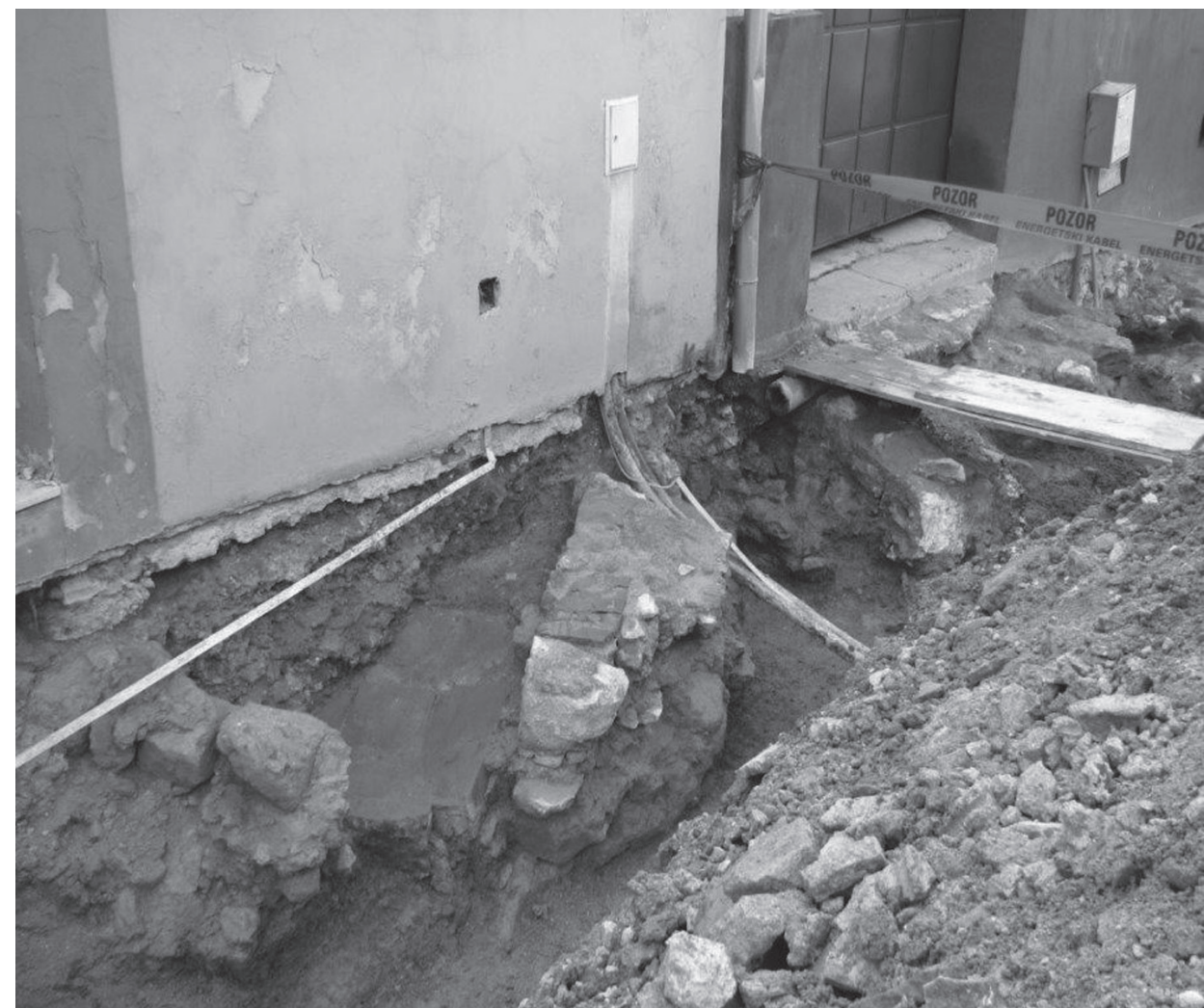

Slika 15. Pogled na segment otkrivene antičke strukture objekta s očuvanim podom od opeke kod kućnog broja 5, Ulica braće Radić, foto: Spomenka Vlahović, 2012.

U grupi građevinskih nalaza izdvojena je i rimska opeka za izgradnju hipokausta. Većina nalaza te grupe također sadrži ostatke žbuke na površinama. Zajednička karakteristika većine nalaza te vrste je da su izrazito narančaste boje pečenja.

Od nalaza spomenute grupe zanimljivi su i nalazi rimskih krovnih opeka, tzv. tegula, koje čine najbrojniju grupu pokretnih nalaza i svjedoče o jakoj antičkoj građevinskoj aktivnosti na lokaciji današnje Ulice braće Radić u Varaždinskim Toplicama. Radi se o elementima koji su bili montirani na krovne konstrukcije javnih ili privatnih objekata. Ono što karakterizira ovu grupu nalaza, posebno su očuvane istake koje se nalaze na rubnim dijelovima nalaza na koje su Rimljani 
SPOMENKA VLAHOVIĆ: Nekoliko crtica o otkrivenim kasnoantičkim fragmentima fresaka i arheološkim...

postavljali drugu vrstu opeka, tzv. imbrex. ${ }^{24}$ Većinom su crvene boje s nadodanim sitnim agregatom u obliku čvrsta pijeska i usitnjene rimske opeke. Na svim površinama mogu se uočiti tipični tragovi obrade u obliku kraćih i dužih linija kao i ostaci razne skrame sive boje od prelijevanja termalne vode, kao i ostaci razne žbuke i gareži. Od zanimljivih otisaka očuvani su tragovi žlijebljenja površine, otisak pasje šape ili otisak nogu manje ptice. Nalaz pod brojem 130 pokazuje još uvijek zanimljive urezane romboide koji su dosta duboko urezani u površini materijala, nalaz je izrazito tamnosmeđe boje pečenja.

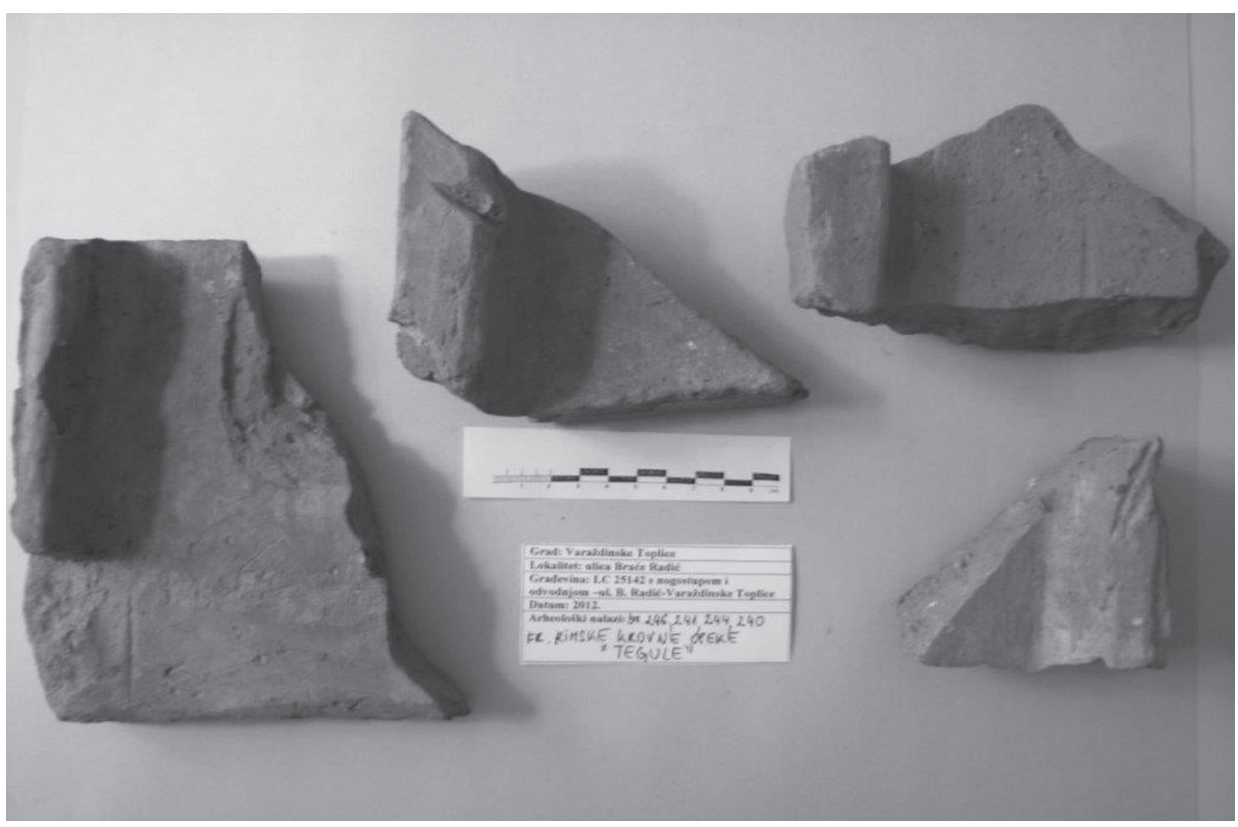

Slika 16. Otkriveni fragmenti rimskih tegula s istakom, foto: Spomenka Vlahović, 2012.

Posljednju skupinu građevinskih elemenata čine fragmenti krovne opeke imbrex koja je montirana na krovne konstrukcije objekata.

Prikazani grafikon u nastavku teksta pokazuje detaljni statistički prikaz otkrivenog pokretnog arheološkog materijala. Može se primijetiti da nalazi rimskih tegula, uz nalaze kostiju, čine najbrojniju grupu pokretnih arheoloških

24 Više podataka o tegulama i imbexima vidi u članku: Heinz SPERLING, "Rekonstruktion von Betriebsmodellen antiker Produktionsanlagen mit Hilfe von Prozessketten-Analysen-Methodik und Fallstudien bei der Ziegelherstellung, Brenholzgewinnung und den Transporten in römischer Zeit" u poglavlju „Ziegelherstellung- Dachziegel tegulae-imbrices“, str. 43-45, Propylaeulll Fachinformationsdienst Altertumswissenschaften, Universitätsbibliothek Heidelberg, 2020, https://www.propylaeum.de 
nalaza, što potvrđuje, zajedno s ostalim očuvanim nalazima djelomično otkrivene rimske arhitekture u Ulici braće Radić, vrlo važan novi segment dijela vrijedne antičke arhitekture nadaleko poznatog antičkog lokaliteta Aquae lasae.

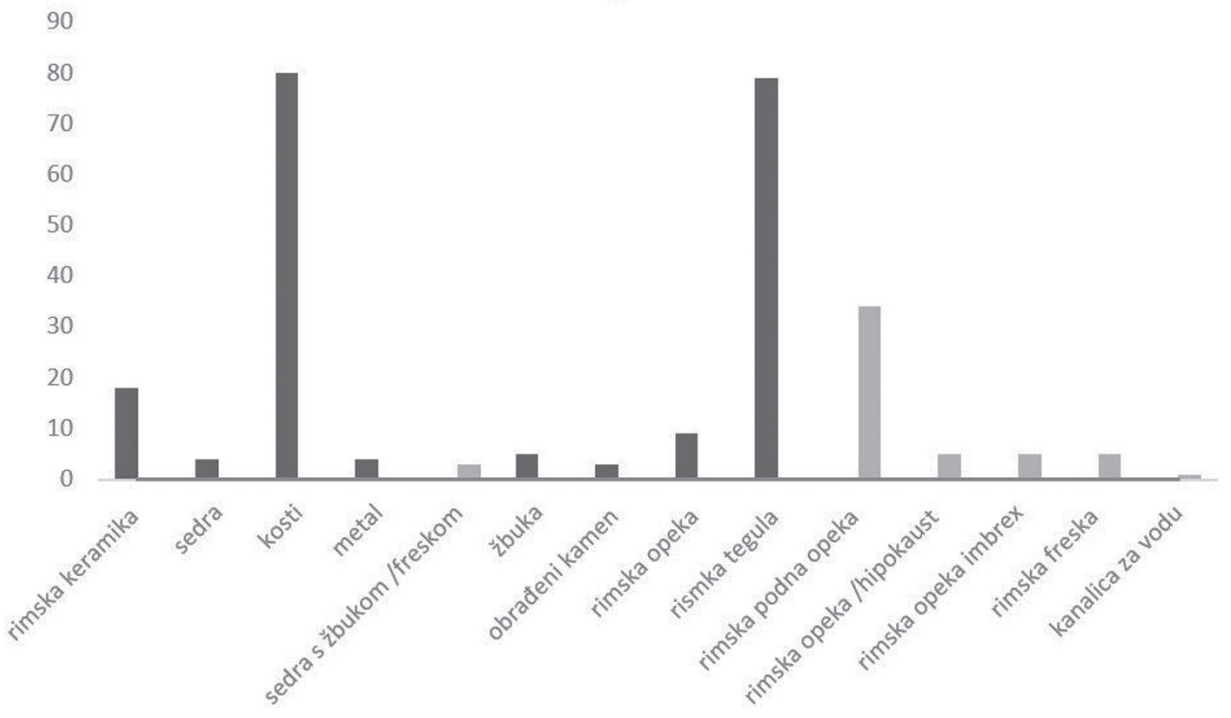

Grafikon 1. Brojčani podaci za pokretne arheološke nalaze iz Ulice braće Radić u Varaždinskim Toplicama, 2012.

\section{ZAKLJUČAK}

Arheološki i konzervatorsko-restauratorski podaci iz Ulice braće Radić govore o dosad nepoznatom očuvanom dijelu rimskih zidnih i podnih struktura koje su nekada bile dekorirane u tipičnoj fresko tehnici. Arheološki nalazi iz čišćenja ostataka zidne strukture, raznolik rimski građevinski materijal i nalaz rimske zdjelice pod brojem 177 govore u prilog kronološkog okvira od 2. do 4. stoljeća.

Dobivenim podacima arheološkog nadzora i provedenog zanimljivog istraživanja u Varaždinskim Toplicama postupno se nadopunjuje arheološka slika zanimljivim novim podacima koji govore u prilog činjenici kako se antičko naselje Aquae lasae prostiralo na području današnjeg grada Varaždinskih Toplica. Svi prikupljeni novi podaci i arheološki nalazi ostat će pohranjeni u Zavičajnom muzeju Varaždinske Toplice, a dobiveni novi terenski podaci koristit će se u znanstvene i muzeološke svrhe s ciljem kulturno-turističke promocije bogate antičke baštine grada Varaždinske Toplice. 


\section{LITERATURA}

1/ Spomenka VLAHOVIĆ, "Stručno arheološko izvješće za istraživanje i nadzor u Ulici braće Radić u Varaždinskim Toplicama za potrebe rekonstrukcije srednjotlačnog plinovoda i ostalih instalacija u 2012.", Zavičajni muzej Varaždinske Toplice.

2/ Erika BRÖDNER, „Die römischen Thermen und das antike Badewesen - Eine kulturhistorische Betrachtung" u "Die Hypokausten“, Wissenschaftliche Buchgesellschaft Darmstadt, 1983., str. 18-24.

3/ Dagmar DAMMANN, "Untersuchung der Putzfragmente aus der Straße Braće Radić geborgen bei Straßenbauarbeiten in Varaždinske Toplice", 7. 10. 2012, Heimatsmuseum Varaždinske Toplice, Kroatien.

4/ Ernst KÜNZLI, "Die Thermen der Römer" u "Ausstattungsluxus: Bildwerke, Brunnen, Bibliotheken", Konrad Theiss Verlag Gmbh, Stuttgart, 2013., 93.

5/ Željko ŽIGROVEČKI GOBAC, Hrvoje POSILOVIĆ, Vladimir BERMANEC, "Identification of biogenetic calcite and aragonite using Sem", Geologica Croatica 62/3. Zagreb, 2009., str. 201-206.,

6/ Jasmina BAVOLJAK, Katalog izložbe „Pompeji - Život u sjeni Vezuva“, Galerija Klovićevi dvori, Zagreb, 2011., 192-197.

7/ „Perseus Digital Library“ u Naturalis Historia, Plinije Stariji, catalog.perseus. org/catalog( op.a.).

8/ Anita RIECHE i Hans JOACHIM SCHALLES, Ursula HEIMBERG "Colonia Ulpia Traiana-Arbeit-Handwerk und Berufe in der römischen Stadt", u „Maurer" i "Maler" , 50 - 53., Rheinland-Verlag Gmbh, Köln, 1987.

9/ Marcus VITRUVIUS POLLIO, Deset knjiga o arhitekturi, VII. knjiga, poglavlje V.: "O zidnim slikama“, str. 148-149., prijevod s latinskog dr. Matija Lopac, Svjetlost, Sarajevo, 1990.

10/ Andrea GIARDINA, „Der Mensch der römischen Antike“ u Jean-Paul Morela „Der Handwerker", Magnus Verlag Gmbh, Essen, 2004., 243-276.

11/ Branka VIKIĆ-BELANČIĆ, Marcel GORENC, „Arheološka istraživanja antiknog kupališta u Varaždinskim Toplicama od 1953.-1955., Vjesnik Arheološkog muzeja u Zagrebu, Zagreb, 1958.

12/ Spomenka VLAHOVIĆ, „Prikaz konzervacije tubula u prostoriji 1 u području terma antičkog kompleksa Aquae lasae u Varaždinskim Toplicama“, , Historia Varasdiensis: časopis za varaždinsku povjesnicu, Vol.1. No. 1, Varaždin, 2011., str. 43-53.

13/ Marcus VITRUVIUS POLLIO, „Deset knjiga o arhitekturi“, VII, „O polaganju podova", str. 142-144. 
Radovi Zavoda za znanstveni rad HAZU Varaždin; br. 31, 2020, str. 9-29

14/ Heinz SPERLING, "Rekonstruktion von Betriebsmodellen antiker Produktionsanlagen mit Hilfe von Prozessketten-Analysen-Methodik und Fallstudien bei der Ziegelherstellung, Brenholzgewinnung und den Transporten in römischer Zeit", Ziegelherstellung-Dachziegel tegulae-imbrices, str. 43-45, PropylaeullI Fachinformationsdienst Altertumswissenschaften, Universitätsbibliothek Heidelberg, 2020, https://www.propylaeum.de

\section{SUMMARY}

\section{SOME DASHES ABOUT LATE ANCIENT DISCOVERED FRESCO FRAGMENTS AND ARCHAEOLOGICAL FINDINGS FROM THE BROTHERS RADIĆ STREET IN VARAŽDINSKE TOPLICE}

The work brings to light the discovery of five late Roman fragments of frescoes discovered during a protective archaeological survey on brothers Radić street in Varaždinske Toplice. Particular attention was paid to the work of conservation and restoration analysis of the discovered murals, as well as to the new discovery of the perserved architectural part of the partially perserved Roman walls at the location of brothers Radić street in Varaždinske Toplice. The text also gives an overview of the newly discovered movable archaeological material that was saved by the works at the specified location. A particularly valuable and interesting ancient building structure was discovered at the house number 5, 7 and 8 . The conducted field research has confirmed that it represents a new preserved important segment of the Roman wall and floor structure with preserved parts that still have a Roman plaster and hypocustic system. The discovered ancient structure was very likely in antiquity an important architectural segment of the widely known ancient settlement Aquae lasae whose original remains are located today near the aforementioned street location in a nearby city park in the center of Varaždinske Toplice.

This paper presents the latest conservation, restoration and archeological data related to the historical urban fabric of the ancient period, which have been preserved under the existing recent residential-architecture of Varaždinske Toplice.

Key Words: antiquity; Aquae lasae; Varaždinske Toplice; movable and immovable archaeological sites. 
